\title{
ECONOMY
}

\section{MAIN FEATURES OF CHINA-KAZAKHSTAN ECONOMIC INTEGRATION}

\author{
PhD Candidate Gelvig Svetlana \\ China, School of Business, \\ Hunan University of Science and Technology
}

DOI: https://doi.org/10.31435/rsglobal_sr/31032020/6997

\section{ARTICLE INFO}

Received 25 January 2020

Accepted 14 March 2020

Published 31 March 2020

\section{KEYWORDS}

China, Kazakhstan, international economy, economic integration, trade.

\begin{abstract}
Kazakhstan is the largest and most developed state among Central Asian countries, with rich base of natural resources. In its foreign policy, Kazakhstan places the development of good-neighborly relations with China on the first place. In turn, for the People's Republic of China, Kazakhstan is the second largest trading partner after Russia and the biggest hub for further transportation of goods, which has big positive effect on economic relations between these two countries. The Chinese factor is constantly operating for the foreign policy of the Republic of Kazakhstan. This paper studies economic integration and main features of trade and economic cooperation in ChinaKazakhstan relations.
\end{abstract}

Citation: Gelvig Svetlana. (2020) Main Features of China-Kazakhstan Economic Integration. Science Review. 3(30). doi: 10.31435/rsglobal_sr/31032020/6997

Copyright: (C) 2020 Gelvig Svetlana. This is an open-access article distributed under the terms of the Creative Commons Attribution License (CC BY). The use, distribution or reproduction in other forums is permitted, provided the original author(s) or licensor are credited and that the original publication in this journal is cited, in accordance with accepted academic practice. No use, distribution or reproduction is permitted which does not comply with these terms.

Introduction. Kazakhstan gained its independence on December 16th in 1991; from that time and now on, it became a full subject of international law. After the collapse of the USSR, Kazakhstan have been experienced the acute socio-economic crisis and was one of the first independent state in the region to form a national economic model on the basis of market principles and actively involved in integration processes. A large-scale privatization program has been carried out in the, including enterprises in the commodity industries that form the basis of the country 's economy, and foreign investment has begun to be actively attracted. China's role in the world economy and global politics is constantly increasing. By many economic measures, today's Beijing represents one of the key centers of political strength on the international stage, competing with the United States. One of the most important factors that positively influenced the development of bilateral relations was that the PRC was one of the first states to admit the independence of Kazakhstan. January 2020 marked the 28th anniversary of the establishment of diplomatic relations between the two countries. Interaction between Kazakhstan and China in different spheres makes it possible to talk about high rates of cooperation, where parties actively work together within SCO, CICA, EAEU.

A significant amount of research is devoted to the analysis of cooperation between China and Kazakhstan in the field of economics. The involvement of the two countries in the global economy is a continuation of the globalization trend; it is desirable from the point of view of international stability. This will help to avoid conflicts in the Central Asian region and create a balance of interests that will be beneficial to all countries. Kazakhstan and China are active participants of economic integration in the region and the implementation of the "One Belt, One Road" initiative contributes to the further economic development for the whole Central Asia. In the study of bilateral relations and investment, Brian G. Carlson (2011) conducted a comparative study on the relationship between Kazakhstan and three major partners in the article "Waving the flag of Independence: the relationship between 
Kazakhstan and Russia, China and the United States"[1], which examined the relationship between Kazakhstan and Russia, China and the United States. All three countries are much stronger than Kazakhstan, but Astana's balance strategy provides leverage for each other. In the author's opinion, despite Kazakhstan's emphasis on good relations with the three major countries, Kazakhstan's foreign policy priorities are quite obvious: the relationship with Russia is the most important, ranked in priority with China, then the United States, the European Union, and finally other Central Asian countries. Carlson mentioned that although Russia remains Kazakhstan's most important security partner, China's role is rapidly growing, especially in the energy and oil fields. Now in the field of energy, China has provided Kazakhstan with a particularly valuable opportunity, because China has provided Kazakhstan with exports of oil and gas to the Pacific Ocean. This is the best opportunity for China to provide diversified energy export routes to countries far away from Kazakhstan.

In the strategic analysis of Kazakhstan China Relations (2011), Richard Roussea discussed the basic issues of Kazakhstan-China relations. Kazakhstan now looks to China as an important and strong partner in the economic, political and security fields [3]. The economic and trade relations between the two countries have been further strengthened over the years. China's willingness and ability to invest in Kazakhstan has always been a major factor in the strengthening of bilateral trade relations. Rousseau marked that these developments show that Kazakhstan plays an increasingly important role in China's regional strategy for Central Asia.

Laumulin M. in his work "Central Asia in Foreign Political Science and World Geopolitics" A., 2008, indicates that the first contacts at a high political level undoubtedly gave impetus to the development of trade and economic ties [2]. The process of mutual grinding in and searching for promising areas of cooperation has begun. The border areas began to work actively, especially in China they were granted very large rights in foreign economic activity. Syroezhkin K. in his article "Problems of Modern Kazakhstan-Chinese Relations" emphasizes that China is a strategic partner not only for Kazakhstan, but also for all of the Central Asian states [6]. This imposes certain obligations, including those related to the level of Chinese economic presence in the region. For Beijing, Central Asia remained a market for Chinese goods, a source of natural and other resources, as well as a transit territory. For more expanded cooperation in future, it is necessary to learn how to use the Chinese interest in Kazakhstan and the how to make Chinese presence to bring more benefits for the socioeconomic development of Kazakhstan.

Cao Lu and Zheng Guofu (2006) analyzed the commodity structure of Kazakhstan China trade, and believed that the development of bilateral trade between Kazakhstan and China is gradually developing and constantly rising [4]. The export structure of China to Kazakhstan is optimizing year by year, and bilateral trade will usher in a leap from low level to high level. By comparing their advantages in the three fields of geography, economy and politics, they affirmed the strong complementarity between Kazakhstan and China, and provided broad development space and lasting power source for the in-depth development of bilateral trade cooperation. At the same time, with the healthy, rapid and all-round development of bilateral trade cooperation, the complementary advantages between the two sides have been further strengthened, thus forming a virtuous circle of interaction. Chinese researches Guo Yajing and Xu Xiaoli [5] in 2008 analyzed the factors influencing the export growth of Kazakhstan and China, studied the potential of the future trade development of the two countries, and pursued for the source of promoting the growth of bilateral trade between Kazakhstan and China. It is pointed out that the benign competition of bilateral trade between Kazakhstan and China is conducive to the stability of Kazakhstan's trade development. Sun Li (2011) believes that Kazakhstan has a wide range of imported goods, which are basically finished products, and part of them are imports driven by Chinese enterprises' investment projects in Kazakhstan [6]. In terms of industry, China's investment in Kazakhstan has expanded from the energy sector to the non-energy sector. It is pointed out that Chinese products have strong competitiveness compared with Russian and Belarusian products, and it is difficult for the customs union to exclude Chinese products.

For the moment, China is home for about 2 million ethnic Kazakhs. Chinese Kazakhs speak Kazakh language using the Arabic alphabet, and also have knowledge of the main Chinese dialect and can speak Mandarin. Many Kazakhs live and study in major cities such as Beijing and Shanghai, but Xinjiang-Uighur Autonomous Region is a traditional sphere of Kazakhstan's political counter-interests. The initial stages of economic relations between Kazakhstan and China were characterized by a rather high economic growth rate. While in 1986 the volume of trade between Kazakhstan and Xinjiang 
amounted only for $\$ 3$ million, in 1987 it rise for $\$ 11.8$ million, and in 1989 already reached $\$ 45.6$ million. By 1991, just before Kazakhstan gained independence, its economic relations with China were already relatively well developed. The PRC became one of the main Kazakhstan's trading partners outside the territory of the former Soviet Union, and 52\% of all its exports to the countries of the so-called "far abroad" were in China.

In the middle of 1989, an agreement on economic, technical and trade cooperation for the period 1989-1995 years was signed between the Xinjiang-Uighur Autonomous Region and Kazakhstan. The total value of all transactions under the agreement was over $\$ 1.5$ billion, and the trade turnover between these neighboring regions was expected to reach $\$ 220-260$ million by 1995 . In July 1991, during N. Nazarbayev's visit to the XUAR, the "Agreement on Principles and Main Directions of Cooperation Development between the Kazakh SSR and Xinjiang" was signed. In addition, on July $31^{\text {st }}$ in 1991, an agreement between Kazakhstan and XUAR was signed in Kulja, providing for so-called "shop tourism", which is calculated only in freely convertible currency. Due to the collapse of the Soviet Union and the transition of the Kazakh SSR to the status of an independent republic, full obligations under these agreements were not fulfilled in the planned amount, but interest in the development of trade and economic cooperation on both sides was obvious. Hence, the basic principles and mechanisms of economic relations between Kazakhstan and China were laid down in the 1980s. During that period it becomes obvious that Xinjiang-Uighur Autonomous Region will be Kazakhstan's main trading partner in the PRC. In addition, joint interest in the development of mutual trade, economic and scientific-technical cooperation became more visible.

After the 2000s, several distinct trends have been observed in the development of KazakhstanChina economic relations: 1 . The beginning of joint promotion in major economic projects; 2 . The increased attention of the PRC to the development of energy cooperation with Kazakhstan; 3. Significant increase in the volume of foreign trade operations and the improvement of Kazakhstan's foreign trade balance. The largest joint economic projects of this period include:

* March 2003 - bringing into operation the Kenkiyak-Atyrau pipeline in western Kazakhstan. The length of the pipeline was $448.8 \mathrm{~km}$, and the design throughput was to reach 12 million tons of oil per year. During reverse operation, this oil pipeline became the first part of the large West Kazakhstan-China oil pipeline, a memorandum on the construction of which was signed back in 1997.

* May 2004 - CNPC acquired a state-owned block of shares of CNPC Aktobemunaigaz for $\$ 150.2$ million (25.12\%), so Chinese company became the sole owner of the company.

*August 2004 - CNPC acquired 35\% interest from Saudi Nimir Petroleum Ltd. in Texaco North Buzachi Inc. Northern Buzachi field.

* October 2004 - reopening of the 1997 project, which included the construction of the Western Kazakhstan-China oil pipeline.

* On May $17^{\text {th }}$ in 2004, Nursultan Nazarbayev and Hu Jintao signed a special agreement on the construction of the Atasu-Alashankou oil pipeline.

* In 2005, the purchasing of oil assets in Kazakhstan was continued. In April, CNODC became the sole shareholder of Kyzylorda Ai-Dan Munai JSC. The main activities of this company included oil and gas operations in the Republic of Kazakhstan, including exploration and drilling, production, preparation and processing, transportation and storage, marketing and trade, export of hydrocarbons and their products.

* In August 2007, the Canadian-registered company Petro Kazakhstan Inc., the fourth largest mining company in Kazakhstan, announced the signing of an agreement under which a subsidiary of CNPC bought back $100 \%$ of its shares for $\$ 4.18$ billion. In the same month, KazMunayGas and CNPC concluded an agreement on joint development of investments justification in the construction of a gas pipeline from Kazakhstan to China.

* In September 2007, KazMunayGas and CNPC signed a memorandum of understanding on CNPC's participation in the development and exploration of the Darkhan field in Kazakhstan sector of the Caspian Sea. In 2008, two more projects in the oil and gas industry on the construction of the Western Kazakhstan-China oil pipeline's second stage, as well as on Kazakhstan joining the project for the construction of a gas pipeline from Central Asia to China, were on the agenda. These projects were agreed back in December 2007 during N. Nazarbayev visit to Beijing, and agreements on them were signed in August 2008, when Hu Jintao visited Astana. The core of the first project is the construction of the Atasu-Kenkiyak oil pipeline, which gives China direct access to Caspian oil, and 
therefore allows the Atasu-Alashankou pipeline to reach its design capacity of 20 million tons per year. The project was completed in 2010. The essence of the second project is Kazakhstan's connection to the construction of Turkmenistan-China gas pipeline. The agreement signed by China with Turkmenistan provides for the supply of 30 billion cubic meters of Turkmen gas to China in 20092038. Kazakhstan plans to add its 10 billion cubic meters to this volume and simultaneously provide gas to the southern regions of the republic.

However, not only the activation of China in the oil and gas sector of Kazakhstan was main characteristic of Kazakh-Chinese economic relations in the first half of the 2000s. Even the official data of Kazakhstan statistics allow us to conclude not only about a significant increase in the volume of foreign trade operations, but also about a change in the nomenclature of foreign trade operations, as well as an improvement in the balance of Kazakhstan in trade with China. In addition, this period is characterized by an increase in foreign direct investment in the economy of Kazakhstan. Chinese investment increased from $\$ 64.7$ million in 2001 to $\$ 195.0$ million in 2005, amounting to $3.04 \%$ of total FDI. As the analysis shows, it was in 2000-2005 that a peculiar "Chinese boom" was observed in Kazakhstan. In 2000, 374 enterprises with the participation of Chinese capital were registered, in 2001 - 874, in 2002 - 975, in 2003 - 665, in 2004 - 579 and in 2005 - 129 enterprises. Actually, most of these enterprises belonged to the sphere of trade, even though biggest part of them did not begin to work, but the fact remains - the interest of Chinese businessmen in Kazakhstan was huge.

The bilateral trade volume of the two countries fluctuates slightly in different years, and the trade structure changes with the total amount of import and export. At present, China has become Kazakhstan's second largest trading partner, and the economic and trade cooperation between the two countries is developing well as a whole. Within this area, in 2011 the trade volume between China and Kazakhstan reached 20 billion US dollars (only 8.3 billion US dollars in 2006), which is much larger than that between Kazakhstan and Russia. The bilateral trade volume increased from 432 million US dollars in 1992 to 10.5 billion US dollars in 2017 [7], showing the dynamic growth of bilateral trade volume and further strengthening China's foothold in Central Asia. In terms of economic relations, more improvements can be expected.

At the end of September last year, entrepreneurs from China and Kazakhstan held a meeting to discuss trade between the two countries. Wu Bangguo, chairman of the Standing Committee of the National People's Congress, took this opportunity to talk about future cooperation opportunities in energy, mineral resources, highway and railway construction, metallurgy, telecommunications and other fields. At present, in terms of economy and trade, China is one of the major foreign trade partners of Kazakhstan. Its share in Kazakhstan's commodity turnover was $15.7 \%$ (\$11.7bn) in 2018 [8]. Chinese statistics say that the trade turnover between the two countries over the past year amounted to $\$ 18$ billion, a comparable increase of 37.4 percent. It is quite possible to reach an even greater annual increase. It is especially worth noting that last year China imported wheat, sunflower seeds and other agricultural products from Kazakhstan, which exceeded 500,000 tones, a comparable increase of 20 percent, which was a new and significant event in bilateral trade [8].

Currently, Kazakhstan is China's first trading partner in Central Asia and the second among Commonwealth of Independent States (CIS) countries. China is the second trade partner of Kazakhstan in the world. The main export commodities of Kazakhstan to China are mineral products, metal and chemical products, and the import commodities from China to Kazakhstan are textiles, machinery, equipment, metals, minerals, ceramics and glass products and consumer goods. However, in the past 10 years, due to the enhancement of global green awareness and development of all kinds of new energy, China's dependence on primary energy products has declined, and the bilateral import and export products have changed from labor-intensive to technology intensive and capital intensive, which is significantly reflected in the construction of infrastructure. The large-scale construction of infrastructure has also indirectly driven the development of domestic catering industry, cleaning industry, small commodity retail industry and other tertiary industries in Kazakhstan.

According to statistics from the Customs Control Committee of the Republic of Kazakhstan, China became the third largest trading partner of Kazakhstan in 2008. In 2009, China climbed to second place in terms of trade volume: as the largest importer (12.6\% of Kazakhstan's total imports) and exporter (13.6\% of Kazakhstan's total exports) of Kazakhstan in 2009 (Fig. 1). 


\section{IMPORTS (PERCENT OF TOTAL IMPORTS)}

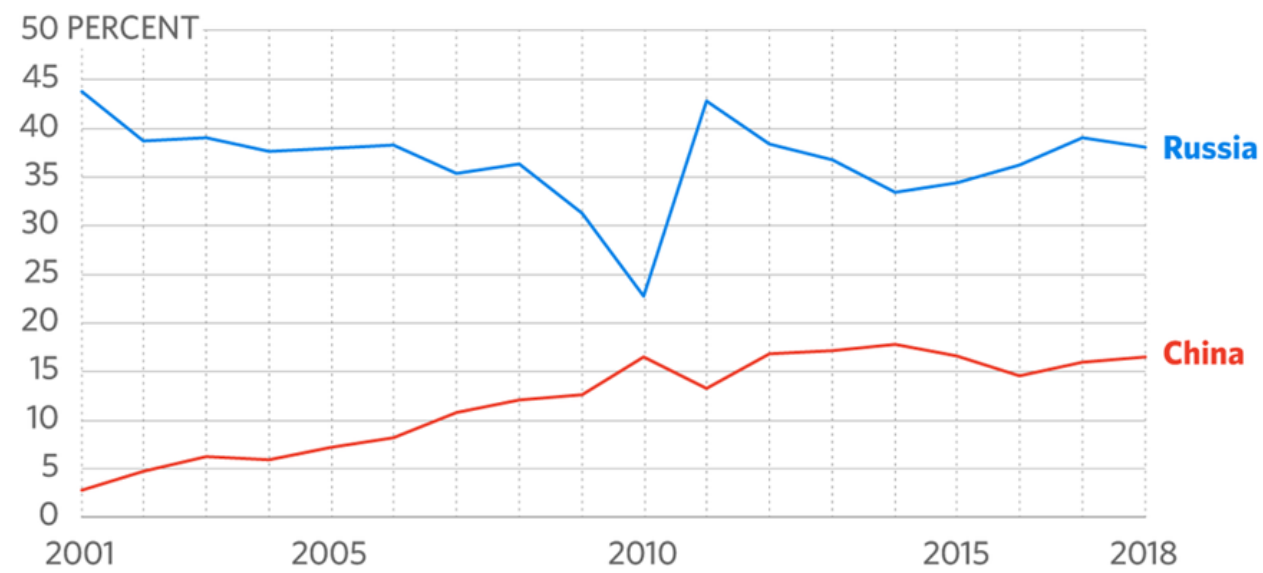

Fig. 1, Kazakhstan Trade with Russia and China (Imports), 2001-2018. Source: International Monetary Fund, 2019.

Historically, Kazakhstan's trade and transportation systems have been oriented towards Russia and former Soviet republics. The railroad network has eleven connecting points with Russia, two with Uzbekistan and one with Kyrgyzstan and China [9]. Same may be said for the trade and energy system. The average growth in bilateral trade from 2000 to 2009 was 36.1\%. According to the Customs Control of the Republic of Kazakhstan, Kazakhstan exports to China are characterized by a raw material orientation. So, in 2009, oil and basic minerals exported from Kazakhstan to China accounted for $52.9 \%$ of the total exports, in particular, crude oil - 38.7\%, copper and copper alloys $-11.4 \%$, natural uranium $-9.7 \%$, iron ore and concentrates $-7.6 \%$

\section{EXPORTS (PERCENT OF TOTAL EXPORTS)}

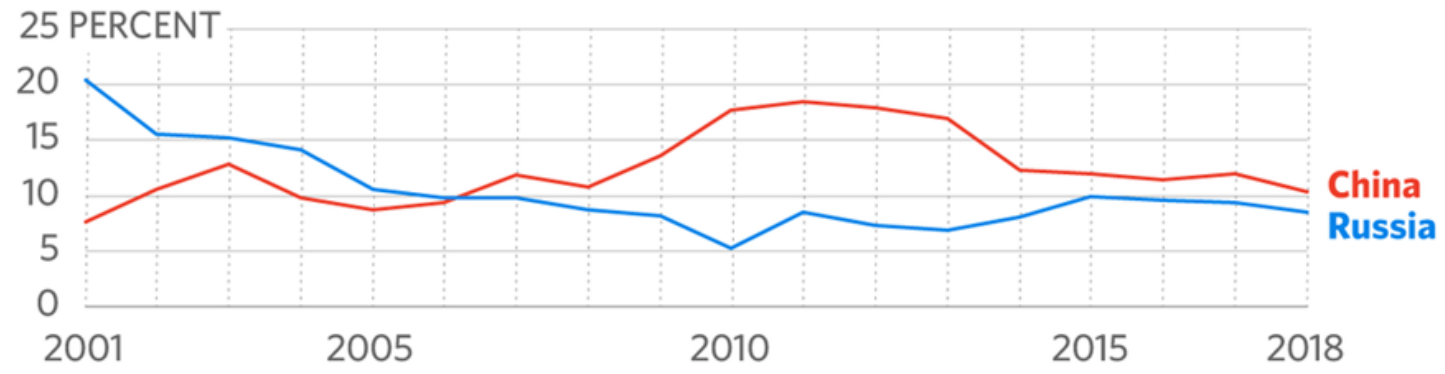

Fig. 2, Kazakhstan Trade with Russia and China (Exports), 2001-2018. Source: International Monetary Fund, 2019.

According Fig. 1 and Fig. 2 we can see that China become an increasingly important trade partner for Kazakhstan over the last two decades, overtaking Russia as the Central Asian country's primary export destination and seeing steady growth as an importer. Independence brought the opportunity to diversify the country's economy via access to new markets. Transportation infrastructure construction is one of the main projects, which aims to establish multi-dimensional, network connected, multi-modal transport channels along the new economic "belt". In terms of the transportation construction and technology facilities, the two sides reached a high degree of agreement.

The following Chinese goods were imported into Kazakhstan in 2009: steel pipes (26.7\% of the total imports) and equipment represented by snowplows, bulldozers, graders, scrapers, excavators and other construction equipment, which accounted for $2.0 \%$. The data show that imported goods from China are diverse, some of them are the result of investment projects of Chinese enterprises in Kazakhstan. Foreign direct investment (FDI) also reflects the degree of trade and economic cooperation. From 1993 to 2009, investment activity in Kazakhstan intensified, the volume of FDI approached 108.05 billion dollars. USA, China accounted for 3.8 billion dollars (3.52\% of total FDI). Mostly capital is invested in the oil and gas sector. 
The volume of trade between Kazakhstan and China in 2013 increased by $11.3 \%$ to $\$ 28.5$ billion. According to the statistics, in the total volume of trade, Kazakhstan's exports to China amounted to $\$ 16$ billion (an increase of 14\%), Kazakhstan's imports from China - \$12.5 billion (an increase of 9.3\%) [10]. Kazakhstan's surplus in trade with China is \$ 3.5 billion. In general, according to the results of 2013, China's export volume grew by $7.9 \%$ to 2.21 trillion dollars. The volume of imports also increased by $7.3 \%$ to 1.95 trillion. dollars. The foreign trade surplus of China amounted to 259.75 billion dollars. China's gross commodity turnover for the first time exceeded $\$ 4$ trillion. In 2018 , the volume of export-import increased by $11.4 \%$ and amounted to $\$ 12$ billion. According to the results of 7 months of 2019, the trade turnover between Kazakhstan and China has already exceeded $\$ 8$ billion. Compared to January-July 2018, trade between the countries grew by $31.2 \%$. It is noteworthy that both export and import are growing. Sales in China over the seven months of this year amounted to $\$ 4.6$ billion - one and a half times higher than in 2018. Imports are not growing so fast: by $14.2 \%$ compared to the same period last year. By 2020, Kazakhstan and China intend to increase the volume of trade to $\$ 40$ billion [10].

As Kazakhstan President Kassym-Zhomart Tokayev noted during his state visit to China, over the years of independence, China has invested about \$20 billion in direct investment in Kazakhstan [10]. According to this indicator, China occupies far from leading positions - about 5\% of the total foreign investment. The main areas of China's investments in Kazakhstan remain transport and warehousing, logistics and infrastructure, financial and insurance activities, oil and gas, construction and mining industries. In order to promote the effective connection between China and Kazakhstan in terms of transportation and logistics infrastructure, it is necessary to jointly promote the construction of "Eurasia Land Bridge" multimodal transport corridor (a transcontinental railroad and rail land bridge, currently comprises the Trans-Siberian Railway, which runs through Russia, China and Kazakhstan), jointly build the "Western Europe - Western China" International Corridor, promote the construction of modern multi-functional transport and logistics center, increase the docking cooperation of port construction, highlight the port effect, so as to form roads, railways and airlines. It is very important to strengthen the economic and trade links among regions, improve the optimal allocation and economic efficiency of various economic factors, develop related industries and more job opportunities and economic construction and open up new markets in Kazakhstan. The cooperation in the construction of transport infrastructure between Kazakhstan and China can not only contribute to the creation of transport corridors between Kazakhstan, China and other countries, but also play an important role in the further optimization for the building level of transport infrastructure in the Western Region and the Southeast coastal areas of China, which is conducive to further improving the transport capacity of countries in the region and contributing to the economy, will lay a good foundation for the future development.

Conclusions. For 28 years, Sino-Kazakh relations have gone beyond the usual bilateral cooperation and have become an example of harmonious coexistence and mutually beneficial cooperation between countries. China and Kazakhstan are closely cooperating in the framework of multilateral mechanisms such as the UN, SCO, CICA and others, are closely cooperating in the fight against the "international threats", like terrorism and ensuring regional security and stability, jointly making efforts to ensure international justice, promote economic globalization and support of the multilateral trading system, and strive to ensure that the international order and the international system develop in a more equitable and rational direction.

The bilateral trade and economic sphere occupies an important place in the progressive development of the whole range of Kazakhstan-China relations, in which significant progress in recent years has been largely associated with factors such as the complementarity of economies, geographical proximity, dynamic economic development and the promotion of large-scale reforms in both countries. Kazakh-Chinese trade and economic relations are developing on the basis of important and numerous interstate and intergovernmental treaties and agreements that define the basic principles and directions of mutually beneficial cooperation between the Republic of Kazakhstan and the People's Republic of China. For China, Kazakhstan is an important and largest market in the CIS after Russia. The level of trade development and economic ties between Kazakhstan and China is becoming more dynamic. In recent years, the structure of trade between the two countries has expanded. Due to the joint efforts of the governments and enterprises of the two countries, the state of trade and economic relations is more than satisfactory. Important factors for improvement in bilateral economic relations are the upgrading of the general 
economic situation in Kazakhstan. Especially in the financial sector, in a number of industrial sectors, namely in the oil and gas. As well as the privatization of a number of large industrial facilities by non-state foreign and local companies, and the rapid economic development of the PRC, China's accession to the WTO, an increase in the range of goods manufactured by China and further export.

Recently, there has been a trend of continuous growth in the volume of trade between Kazakhstan and the PRC. This serves as the basis for mutual relations and gives impetus to the development of cooperation between the two countries in all areas. Since Kazakhstan attaches great importance to the development of bilateral relations with China, a number of measures have been taken by the government of Kazakhstan. According to official figures, Kazakhstan's exports in bilateral trade exceed imports. The trade turnover structure between Kazakhstan and China consists mainly of Kazakhstan's sale of oil, ore, coal, ferrous metals, electrolyte copper, nickel, aluminum, as well as livestock products. As for China's deliveries to Kazakhstan, these are mainly goods from the light and textile industries, electric machinery and equipment, etc. Direct and cross-border trade accounts for most of the turnover, of which one third is barter. Many Chinese experts consider the current structure of the Kazakh-Chinese trade balance to be the most optimal and attribute it to one of the important advantages of bilateral trade and economic cooperation. In their opinion, such a complementarity of economic structures, which is based on the ability of Kazakhstan to produce primary raw materials, and China - to process it, will be preserved in the near future.

In general, Kazakhstan is the main object of China's economic interest in Central Asia. The scale of the PRC presence in the Republic of Kazakhstan during the post-Soviet period has been steadily growing and already appear significant. Moreover, if initially the Chinese economic interest mainly affected the trade sector, which was only insignificantly accompanied by the development of transport and communications, today it's clearly visible that more systematic efforts of the PRC is made to intensify project and investment activities in Kazakhstan. And more and more steady tendency to diversify the Chinese presence in Kazakhstan by sectors of the economy began to be observed.

In connection with the territorial proximity of states and the current state of relations between the states of the Republic of Kazakhstan and the PRC, the following conclusions can be drawn: economies;

-the need for cooperation is dictated by the geographical location and some dependence of

- due to the fact that previously both states were in the same socialist camp, and now they are moving to a market economy, cooperation is necessary for the effective development of the both states;

- one of the important features of foreign trade policy is the need to implement it with clearly formulated goals in the form of specific programs. Moreover, the "goal" should not be an analogy of the "plan".

Reforms, openness and social development are mutually supportive. 20 years of reform policy and expansion of foreign relations have become the period of the most rapid economic development and accelerated growth of China's total potential. This was reflected in the rapid development of the productive forces and the comprehensive progress of social life. The same experience should be used by the Republic of Kazakhstan, but only with taking into account national traditions.

Thus, it can be shown that the current dynamics in the development of mutual cooperation in trade, economic, investment, energy, transport and many other areas allows us to optimistically assess the prospects for further building of cooperation between Kazakhstan and China in these areas. Confidently, it is complemented by the fact that the progressive consolidation of this positive trend corresponds to the interests of the two neighboring and friendly countries. Trade and economic relations between Kazakhstan and China have a good long-term perspective. There is no doubt that China's fast-growing economy will demand more and more oil. And therefore, China will consider Kazakhstan as one of its most preferred suppliers of energy and raw materials. In turn, Kazakhstan will also need a large Chinese market.

\section{REFERENCES}

1. Carlson B.G., "Waving the Banner of Independence: Kazakhstan's Relations with Russia, China, and the United States." Yale Journal. January 8, 2011. http://yalejournal.org/wpcontent/uploads/2011/01/083104carlson.pdf (accessed January 5, 2015).

2. Laumulin M., Central Asia in foreign political science and world geopolitics A., 2008.188 p.

3. Rousseau, R., "Kazakhstan - continuous improvement or stalemate in its relations with China." Khazar Journal of Humanities and Social Sciences 14, no. 3 (2011): p.13. 
4. Cao Lu, Zheng Guofu, on Sino Kazakhstan economic and trade cooperation, Journal of Gansu Union University, Social Science Edition, No. 5, 2006 (曹绿, 郑国富, 《中哈经贸合作关系论析》, 《甘肃联 合大学学报》, 社会科学版, 第 5 期, 2006)

5. Guo Yajing, Xu Xiaoli. Analysis of trade complementarity between Kazakhstan and China [J]. Xinjiang finance, 2011 (11) (郭亚静, 徐晓莉. 哈萨克斯坦与中国贸易互补性分析 [J].新疆金融, 2011(11))

6. Syroezhkin K., Problems of Modern Kazakhstan-Chinese Relations, Almaty, Kazakhstan Institute of Strategic Studies under the President of the Republic of Kazakhstan, 2006, pp.299-305.

7. Galdini F., Satke R. Between East and West: Kazakhstan's development along China's New Silk Road / F. Galdini, R. Satke.: OSCE Academy Journal No. 3, 2015. pp.6-12

8. Bangguo W. Chairman of the Standing Committee of the National People's Congress Speech (吴邦国开始 访问哈萨 克斯坦 ) / Wu Bangguo (吴邦国), URL:http://www.npc.gov.cn/npc/c238/201109/0b7a5d78a6b847769b971c3f0164e80d.shtml (accessed on 15.05.2017)

9. International Crisis Group (ICG). Kazakhstan: Waiting for Change / International Crisis Group (ICG).: Asia report No.250, 2013.P.34

10. Serikpaev D., What does China mean for Kazakhstan? Facts and Figures, https://forbes.kz/process/expertise/chto_znachit_kitay_dlya_kazahstana (accessed 12.09.2019)

11. Stepanov, V.V. Features of trade and economic cooperation of the People's Republic of China and the Republic of Kazakhstan / V.V. Stepanov. - Text: direct, electronic // History and archeology: materials of the I Intern. scientific conf. (St. Petersburg, November 2012). - St. Petersburg: Renome, 2012, pp. 24-26. URL: https://moluch.ru/conf/hist/archive/61/2926/ (accessed: 04.21.2020). 